\title{
Talon cusp in a deciduous upper incisor from a medieval Portuguese child
}

\author{
Ana Maria SilvA ${ }^{1 *}$, Ana Cristina SubTIL ${ }^{1}$ \\ ${ }^{1}$ Departamento de Antropologia, Universidade de Coimbra, 3000-056 Coimbra, Portugal \\ Received 18 April 2008; accepted 30 May 2008
}

\begin{abstract}
Talon cusp is a rare developmental anomaly in deciduous and permanent dentition. This paper reports a case of talon cusp affecting the deciduous maxillary left incisor from a Portuguese child who died more than 680 years ago. Metric analysis suggests that the affected tooth is a double tooth. The possible co-existence of these two anomalies in the deciduous dentition, although clinically rare, represents the second archaeological case reported.
\end{abstract}

Key words: dental anomaly, deciduous dentition, double teeth, medieval period, Portugal

\section{Introduction}

Talon cusp is a rare morphological dental anomaly that can occur in both deciduous and permanent dentition. According to the conventional definition, this developmental malformation is manifested as a projection of an accessory cusplike structure from the cingulum area or cementoenamel junction (CEJ) on maxillary or mandible teeth (Hattab et al., 1995; Lehl, 1999; Hattab and Hazza'a, 2001; Glavina and Skrinjaric, 2005). More recently, talon cusp has also been described as affecting the labial surface of the tooth (McNamara et al., 1997; Turner, 1998; De Sousa et al., 1999; Lee et al., 2003; Patil et al., 2004; Glavina and Skrinjaric, 2005; Llena-Puy and Forner-Navarro, 2005). Even rarer is the presence of facial and lingual talon cusps in the same tooth (Abbott, 1998; Dunn, 2004). This anomaly varies extensively in shape, size, structure, location and site of origin (Segura and Jiménez-Rubio, 1999; Segura-Egea et al., 2003a).

In 1892, Mitchell reported the first description of talon cusp on a lingual surface of an upper central incisor in a female patient (Hattab et al., 1995). According to Lomçali et al. (1994) there were no further reports until 1970. Nevertheless, findings described in the last 30 years, mostly clinical cases, show that the condition may be more frequent than previously thought (Lomçali et al., 1994; Dankner et al., 1996).

The purpose of this report is to draw attention to an additional cusp found in the deciduous dentition of one non-adult medieval skeleton, namely in a maxillary left incisor, a condition rarely noted in clinical and archaeological samples.

\footnotetext{
* Correspondence to: Ana Maria Silva, Departamento de Antropologia, Universidade de Coimbra, 3000-056 Coimbra, Portugal.

E-mail: amgsilva@antrop.uc.pt

Published online 1 August 2008

in J-STAGE (www.jstage.jst.go.jp) DOI: 10.1537/ase.080418
}

\section{Case report}

In 2002 during repairs to the internal courtyard of the Grão Vasco Museum in Viseu (Portugal), situated in the churchyard of the Old Church of Sé de Viseu, a medieval cemetery was discovered. Part of the necropolis was excavated during the spring of 2002. The graves were ovalshaped pits containing single burials, with only one exception, grave 26, double inhumation of two children (Perpétuo, 2002). Forty-nine poorly preserved skeletons were recovered, consisting of 39 adults (both sexes) and 10 non-adults. The detailed osteological study of the sample is published elsewhere (Subtil, 2005). The dental abnormally described here was recorded for one of the non-adult skeleton exhumed from grave 26.

Grave 26, an oval pit excavated in the gross sand (maximum length: $126 \mathrm{~cm}$; depth: $47 \mathrm{~cm}$ ) represents the only double sepulchre from the Grão Vasco necropolis. This grave contained two non-adult skeletons (Pinto Reis and Pereira, 2002). The two children, probably inhumed at the same time, were buried side by side, in supine position. Both skeletons were badly preserved and very incomplete. Dental development (following Smith, 1991) indicates an age at death around 3 years \pm 12 months for both children (26A and 26B). The skeleton investigated in this report is labelled 26B.

The dental remains of skeleton 26B (deciduous and permanent teeth), numbering 26 teeth, were recovered as loose teeth with the exception of the deciduous mandibular left first molar. Furthermore, all the preserved teeth display some degree of post-mortem damage, with enamel fractured away or in a delicate condition, and in the deciduous teeth, parts of the root were broken away. A cranial bone sample from this child was used for dating (AMS): $630 \pm 40 \mathrm{BP}$ (cal 1290-1410 AD, 2 sigma, beta -205246).

The only upper left incisor preserved presents an unusual form: a supernumerary cusp projecting palatally from the cingulum area, extending from the cemento-enamel junction (CEJ) to the incisive edge, producing a $\mathrm{T}$-form crown contour (Figure 1, Figure 2, Figure 3). According to Hattab et 


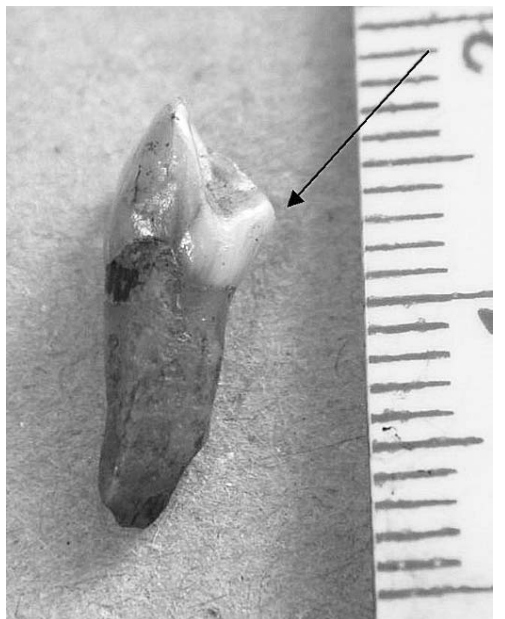

Figure 1. Lateral view of the left primary maxillary incisor Arrows indicate the talon cusps.

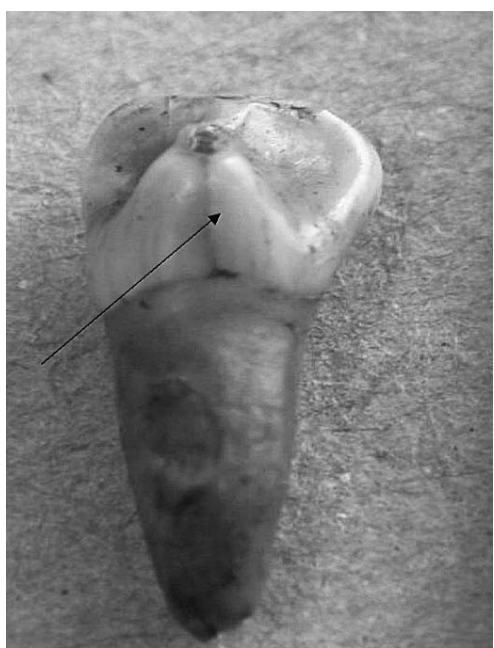

Figure 2. Posterior view of the left primary maxillary incisor. Arrows show the talon cusps.

al.'s (1996) classification, based on the degree of cusp formation and extension, this cusp is of type 1 or true cusp since it is a morphologically well-delineated additional cusp that prominently projects from the palatal surface, extending more than half of the distance from CEJ to the incisive edge. The crown oclusal surface was worn to the third state according to Smith's criteria of dental attrition (Smith, 1984), including on the incisal edge of the anomalous cusp (Figure 3), but no evidence of cariogenic lesions was detected. Radiographic examination (Figure 4, Figure 5) suggests the extension of pulp tissue into the additional cusp (Costa and Conceição, personal communication; Figure 5). However, according to Mader and Kellog (in Güngör et al., 2000), it is nearly impossible to confirm the existence of pulpal tissue in an anomalous cusp by radiographic evaluation; this requires a histological study, which was not possible in the present case.

The complete identification of the maxillary left incisor is

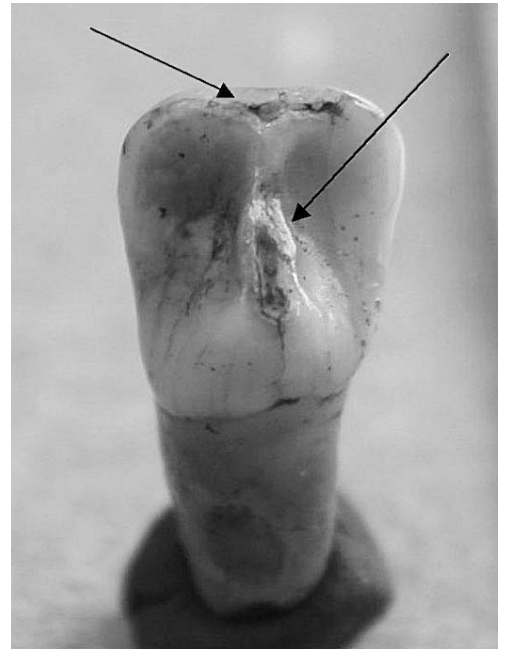

Figure 3. Occlusal view showing dental wear (see arrow), including in the additional cusp (see arrow).

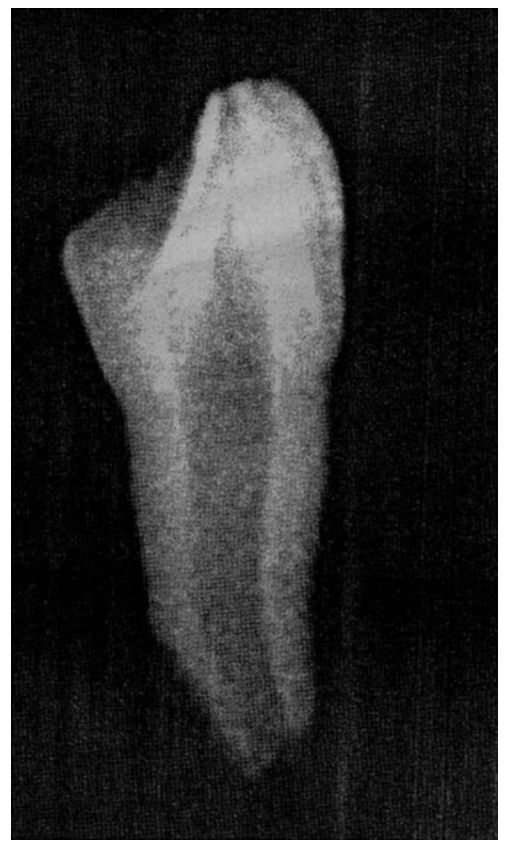

Figure 4. Posterior radiograph of the left primary maxillary incisor

uncertain, since no maxillary bone was preserved and only one maxillary left incisor was recovered. The maximum mesio-distal width of the crown is $5.24 \mathrm{~mm}$; this lies between the values for the two deciduous right upper incisors, the mesio-distal widths of which are $5.58 \mathrm{~mm}$ for the upper central incisor and $4.58 \mathrm{~mm}$, for the lateral one.

All other preserved teeth (deciduous and permanent) are normal (Figure 6).

\section{Discussion}

Talon cusp is a relatively rare odontogenic anomaly. Clinical studies suggest frequencies ranging from less than $1 \%$ to 


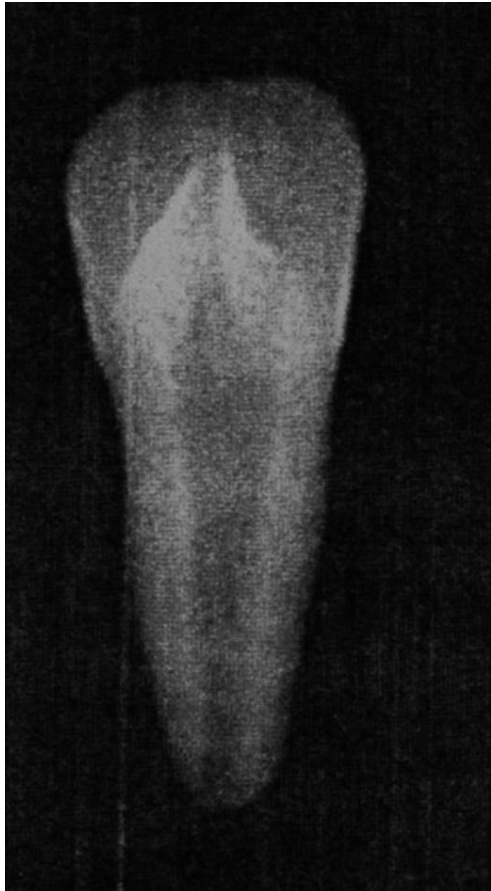

Figure 5. Lateral radiograph of the left primary maxillary incisor.

approximately $8 \%$ of the human population (e.g. Abbott, 1998; Dankner et al., 1996; Dash et al., 2004). Other names for this dental anomaly include dens evaginatus, interstitial cusp, tuberculated premolar, odontoma of the axial core type, evaginated odontoma, occlusal enamel pearl, occlusal anomalous tubercle, and supernumerary cusp (Abbott, 1998; Soares et al., 2001; Dash et al., 2004).

Talon cusp can appear alone or associated with other dental anomalies (somatic and odontogenic), such as pegshaped lateral incisors, unerupted canines and mesiodens, supernumerary teeth, megadont, dens invaginatus, complex odontoma and impaction, hypodontia, partial anodontia, periodontopathy, malocclusion, shovel-shaped incisors, and exaggerated Carabelli cusp (Lomçali et al., 1994; Al-Omari et al., 1999; De Sousa et al., 1999; Hegde and Kumar, 1999; Lehl, 1999; Hattab and Hazza'a, 2001; Segura-Egea et al., 2003b; Dash et al., 2004). Syndromes sometimes associated with talon cusp include Rubinstein-Taybi syndrome, Mohr syndrome, Ellis-Van Creveld syndrome, Sturge-Weber syndrome, and incontinentia pigmenti achromians (Lomçali et al., 1994; Hattab et al., 1995; Güngör et al., 2000; Dash et al., 2004).

Although talon cusp is relatively rare, it is not an entirely innocuous defect since it has an clinical significance: small talon cusps are usually asymptomatic, but large ones may give rise to clinical complications as poor aesthetics, occlusal interference, cusp fracture, displacement of the taloned tooth, caries-susceptible developmental grooves, attrition, irrigation of the tongue, interference with tongue space, attrition causing pulpal exposure or periapical pathology, breast-feeding problems, and temporomandibular joint pain (Harris and Owsley, 1991; Hattab et al., 1995; Al-Omari et al., 1999; De Sousa et al., 1999; Güngör et al., 2000; Ferraz et al., 2001; Mays, 2003; Segura-Egea et al., 2003b).

The etiology of this dental anomaly remains unknown, but

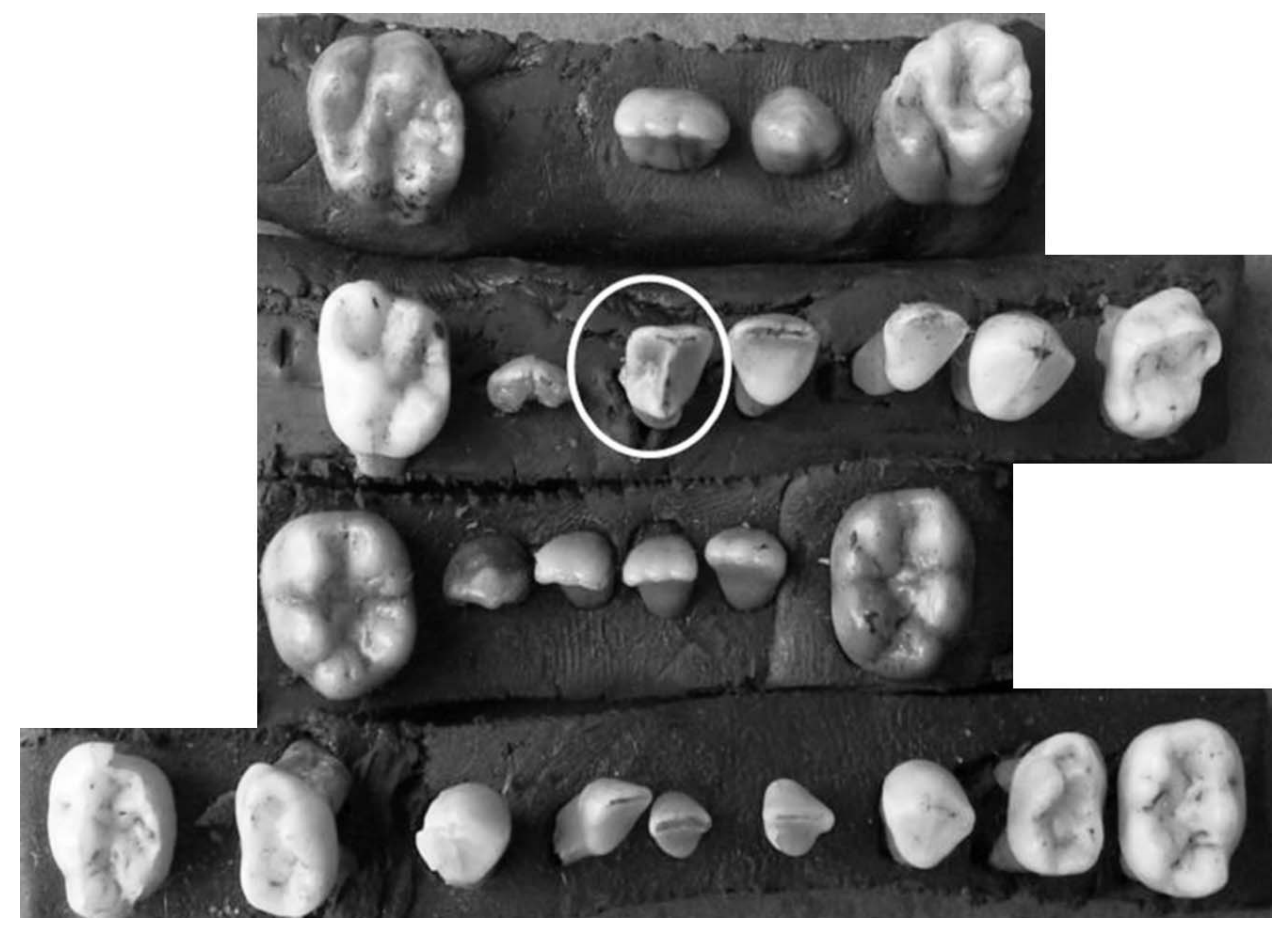

Figure 6. Occlusal view of the preserved deciduous and permanent teeth of non-adult skeleton 26B of the necropolis of Grão Vasco (Viseu, Portugal). From up to down: upper permanent teeth, upper deciduous teeth, lower permanent and lower deciduous teeth. The circle indicates the tooth with the talon cusp. 
it is believed to be multifactorial, including genetic and environmental factors (Soares et al., 2001; Dash et al., 2004). There is literature supporting the hypothesis that the character of talon cusp is hereditary. Family involvement, e.g. patients with consanguineous parents, siblings, and twins, and the association of the talon cusp with other dental abnormalities, suggests that genetics may be a major causative factor, but sporadic occurrences are probably induced by trauma or other localized insults affecting the tooth germ (Segura and Jiménez-Rubio, 1999; Segura-Egea et al., 2003a). As with other dental abnormalities, talon cusp occurs early in odontogenesis, i.e. during the morpho-differentiation stage. According to Hattab et al. (1995), it may occur as a result of outward folding of the inner enamel epithelial cells (precursors of ameloblasts) and a transient focal hyperplasia of the mesenchymal dental papilla (precursors of odontoblasts). Others have suggested that disturbances during morphodifferentition might affect the shape and size of the tooth without impairing the function of ameloblasts or odontoblasts (Dash et al., 2004).

A review of the literature on talon cusps reveals that they occur three times more frequently in permanent dentition than in deciduous dentition, have a greater predilection for the maxilla, and a higher incidence in males (Hattab et al., 1995; Dankner et al., 1996; Segura and Jiménez-Rubio, 1999; Hattab and Hazza'a, 2001). This anomaly is commonly unilateral but one-fifth of the cases are bilateral (Harris and Owsley, 1991; Hattab et al., 1996; Segura and Jiménez-Rubio, 1999). In the permanent dentition, maxillary lateral incisors are most often affected, followed by central incisors and canines (Dankner et al., 1996; Segura and Jiménez-Rubio, 1999; Dash et al., 2004). The susceptibility of lateral incisors to abnormalities such as dens invaginatus, shovelling, and talon cusp could partly be related to compression of the tooth germ of the lateral incisor by the adjacent central incisor and canine, which develop approximately 7 months earlier than the lateral incisor. Thus, the increased localized external pressure on the tooth germ during morpho-differentiation may result in outfolding of the dental lamina (Segura and Jiménez-Rubio, 1999; Segura-Egea et al., 2003a).

Reports of talon cusps in archaeological specimens are rare. These include a talon cusp on a deciduous maxillary central incisor from a mummy of a 5-6 year old Peruvian child, dating 2200 years BP, nine talon-like cusps on the lateral surfaces of incisor teeth in North American human remains (Sawyer et al., 1976; Mays, 2005), and a talon cusp in a deciduous lateral incisor from a medieval child (Turner, 1998; Lee et al., 2003). According to Mays's survey (2005) all talon cusps in deciduous dentition were scored in maxillary incisors, with one exception, in a mandibular deciduous left lateral incisor (Hedge and Kumar, 1999); it is most often an isolated abnormality; there is no preference for expression on the left or right sides; and it is more frequent in Asian populations.

The present case represents one of the few archaeological cases of talon cusp in deciduous dentition. In occlusal view, the affected tooth seems to present a very shallow concavity about halfway along the incisive edge (Figure 6). In addition, its mesio-distal width lies between those of the two right incisors. Possible explanations for these differences can include two developmental anomalies i.e. fusion or gemination. Fusion is the union of dentin and/or enamel of two or more adjacent teeth. Depending upon the stage of the development of the teeth at the time of fusion, the union can be complete (producing an enlarged single tooth) or incomplete and involve different parts of the teeth (coronal part, the radicular part or both) (Alt and Türp, 1998; Mays, 2003). Gemination is another developmental anomaly of tooth shape that results from an abortive attempt by a single tooth to divide (Hattab and Hazza'a, 2001). This is more frequent in deciduous dentition, with a prevalence of $1 \%$ in Caucasian groups (Hattab and Hazza'a, 2001). Fusion diminishes the number of tooth and gemination does not. However, Schuurs and van Loveren (2000) believe that the number of teeth is an untrustworthy diagnostic criterion due to the simultaneous presence of other anomalies such as fusion with a supernumerary teeth or gemination with agenesis of another tooth. Thus, the use of the term double tooth (DT) is preferred when differential diagnosis between fusion and gemination is difficult or impossible (Schuurs and Loveren, 2000; Tomizawa et al., 2002; Gurri and Balam, 2006), as in the present case. DT is also a rare dental anomaly, occurring in about $0.6 \%$ of deciduous and $0.1 \%$ of permanent dentitions in European populations (Schuurs and van Loveren, 2000). The most commonly involved teeth are: the central and lateral incisors, the lateral incisor and the canine. DT is also more frequent in the mandible than maxilla with apparent no sex preference (Schuurs and van Loveren, 2000; Gurri and Balam, 2006). Thus, the present case represents a possible co-existence of two anomalies in the deciduous dentition of an archaeological case. To date, only Mays $(2003,2005)$ has described a case of co-occurrence of talon cusp and DT in the same dental elemental in the deciduous dentition, despite it being recorded in permanent dentition (Lomçali et al., 1994; Hattab and Hazza'a, 2001; Li, 2002).

Furthermore, no clinical complications, e.g. cariogenic lesions, pulpar extension or periapical pathology, were detected. However, it is important to emphasize that, due to the nature of the case, the majority of clinical complications cannot be assessed in archaeological samples.

\section{Conclusion}

This paper describes a talon cusp found in a deciduous maxillary left incisor from a 3 year old child who died around 680 years ago in Portugal. As in present times, this dental anomaly seems to be rare in past populations. It represents the second European archaeological case published, after the talon cusp found in a deciduous lateral incisor from a medieval British child published by Mays (2003, 2005). Furthermore, these two archaeological cases show several resemblances besides chronology: in both cases, the additional cusp was found in the maxillary deciduous left incisor, which probably also represents a DT. In sum, this report is another important contribution to our knowledge of dental variants in past populations (Silva and Silva, 2007). 


\section{Acknowledgments}

We than the Instituto Ambiente e Vida for financial support of the dating of the sample; Rui Marques and Maria Teresa Ferreira (Departamento de Antropologia, Universidade de Coimbra, Portugal) for their comments of earlier drafts of this paper; and Dr. Miguel Costa and Dr. Rui Conceição (dentists) for their help in the interpretation of the radiographs; and the Centro de Investigação em Antropologia e Saúde.

\section{References}

Abbott P.V. (1998) Labial and palatal 'talon cusps' on the same tooth. A case report. Oral Surgery, Oral Medicine, Oral Pathology, Oral Radiology, and Endodontology, 85: 726-730.

Al-Omari M.A.O., Hattab F.N., Darwazeh A.M.G., and Dummer P.M.H. (1999) Clinical problems associated with unusual cases of talon cusp. International Endodontic Journal, 21: 183-190.

Alt K.W. and Türp J.C. (1998). Hereditary dental anomalies. In: Alt K.W., Rösing F.W., and Teschler-Nicola M. (eds), Dental Anthropology. Fundamentals, Limits and Prospects. Springer Verlag, Wien, pp. 95-128.

Dankner E., Harari D., and Rotstein I. (1996) Dens evaginatus of anterior teeth. Literature review and radiographic survey of 15.000 teeth. Oral Surgery, Oral Medicine, Oral Pathology, Oral Radiology, and Endodontology, 81: 472-476.

Dash J.K., Sahoo P.K., and Das S.N. (2004) Talon cusp associated with other dental anomalies: a case report. International Journal of Paediatric Dentistry, 14: 295-300.

De Sousa S.M.G., Tavano S.M.R., and Bramante C.M. (1999) Unusual case of bilateral talon cusp associated with dens invaginatus. International Endodontic Journal, 32: 494-498.

Dunn W.J. (2004) Unusual case of labial and lingual talon cusps. Military Medicine, 169: 108-110.

Ferraz J., Carvalho Júnior J., Saquy P., Pócora J., and Sousa-Neto M. (2001) Dental anomaly: dens evaginatus (talon cusp). Brazilian Dental Journal, 12: 132-134

Glavina D. and Skrinjaric T. (2005) Labial talon cusp on maxillary central incisors: a rare developmental dental anomaly. College of Antropology, 29: 227-231.

Güngör H.C., Altay N., and Kaymaz F.F. (2000) Pulpar tissue in bilateral talon cusps in primary central incisors: report of a case. Oral Surgery, Oral Medicine, Oral Pathology, Oral Radiology, and Endodontology, 89: 231-235.

Gurri F. and Balam G. (2006) Inheritance of bilateral fusion of the lower central and lateral incisors: a pedigree of a Maya family from Yucatan, Mexico. Dental Anthropology, 19: 29-34.

Harris E.F. and Owsley D.W. (1991) The talon cusp: a review with three cases from Native North America. Journal of Tennessee Dental Association, 71: 20-22.

Hattab F. and Hazza'a A. (2001) An unusual case of talon cusp on geminated tooth. Journal of the Canadian Dental Association, 67: 263-266

Hattab F., Yassin O., and Al-Nimri K. (1995) Talon cusp-clinical significance and management: case reports. Quintessence International, 26: 115-120.

Hattab F., Yassin O., and Al-Nimri K. (1996) Talon cusp on the permanent dentition associated with other dental anomalies: review of the literature and report of seven cases. Journal of Dentistry for Children, 63: 368-376.

Hegde S. and Kumar B.R.A. (1999) Mandibular talon cusp: report of two rare cases. International Journal of Paediatric Dentistry, 9: 303-306.

Lee C., Burnett S.E., and Turner II C.G. (2003) Examination of the rare labial talon cusp on human anterior teeth. Dental Anthropology, 16: 81-83.
Lehl G.K. (1999) Talon cusp associated with other dental anomalies - a case report. Journal of Indian Society of Pedodontics and Preventive Dentistry, 17: 13-14.

Li R.W. (2002) Clinical variants in tooth number and crown form: a report of bilateral double teeth associated with talon cusp. Dental Update, 29: 403-408.

Llena-Puy M.C. and Forner-Navarro L. (2005) An usual morphological anomaly in an incisor crown. Anterior dens evaginatus. Medicina Oral, Patologia Oral y Cirugia Bucal, 10: 1316.

Lomçali G., Hazar S., and Altinbulak H. (1994) Talon cusp: report of five cases. Quintessence International, 25: 431-433.

Mays S. (2003) An unusual deciduous incisor in a mediaeval child. Journal of Paleopathology, 15: 159-166.

Mays S. (2005) Talon cusp in a primary incisor from a medieval child. International Journal of Paediatric Dentistry, 15: 67-72.

McNamara T., Haeussler A.M., and Keane J. (1997) Facial talon cusps. International Journal of Paediatric Dentistry, 7: 259262.

Patil R., Singh S., and Subba Reddy V.V. (2004) Labial talon cusp on permanent central incisor: a case report. Journal of Indian Society of Pedodontics and Preventive Dentistry, 22: 30-32.

Perpétuo J.M. (2002) Relatório preliminar 'Museu Grão Vasco, Viseu'. Sondagens arqueológicas de avaliação e acompanhamento. Viseu, field report.

Pinto Reis M. and Pereira C. (2002) Museu Grão Vasco. Relatório preliminar da escavação antropológica. Coimbra, Departamento de Antropologia da FCTUC.

Sawyer D.R., Allison M.J., and Pezzia A. (1976) Talon cusp: a clinically significant anomaly in a primary incisor from preColumbian America. Medical College of Virginia Quaterly, 12: $64-66$

Schuurs A.H.B. and van Loveren C. (2000) Anomalies. Double teeth: review of the literature. Journal of Dentistry for Children, 67: 313-325.

Segura J.J. and Jiménez-Rubio A. (1999) Talon cusp affecting permanent maxillary lateral incisors in 2 family members. Oral Surgery, Oral Medicine, Oral Pathology, Oral Radiology, and Endodontology, 88: 90-92.

Segura-Egea J.J., Jiménez-Rubio A., Ríos-Santos J.V., and Velasco-Ortega E. (2003a) Dens evaginatus of anterior teeth (talon cusp): report of five cases. Quintessence International, 34: $272-277$.

Segura-Egea J.J., Jiménez-Rubio A., Velasco-Ortega E., and RíosSantos J.V. (2003b) Talon cusp causing occlusal trauma and acute apical periodontitis: report of a case. Dental Traumatology, 19: 55-59.

Silva A.M. and Silva A.L. (2007) Unilateral fusion of two primary mandibular teeth: report of a Portuguese archaeological case. Dental Anthropology, 20: 16-18.

Smith B.H. (1984) Patterns of molar wear in hunter-gatheres and agriculturalists. American Journal of Physical Atnrhopology, 63: 39-84

Smith B.H. (1991) Standards of human tooth formation and dental age assessment. In: Kelley M. and Larsen C.S. (eds), Advances in Dental Anthropology. Wiley-Liss, New York, pp. $143-168$.

Soares A., Araújo J.J., Sousa S., and Veronezi M.C. (2001) Bilateral talon cusp: case report. Quintessence International, 32: 283-286.

Subtil A.C. (2005) Paleobiologia da população humana exumada da Necrópole do Museu Grão Vasco. Séc. XIII/XV. Dissertação de Mestrado em Evolução Humana. Coimbra. FCTUC, Universidade de Coimbra. Master's thesis.

Tomizawa M., Shimizu A., Hayashi S., and Noda T. (2002) Bilateral maxillary fused primary incisors accompanied by succedaneous supernumerary teeth: report of a case. International Journal of Paediatric Dentistry, 12: 223-227.

Turner C.G. (1998) Another talon cusp: what does it mean? Dental Anthropology, 12: 10-12. 